\title{
RELATIONSHIP BETWEEN INSTITUTIONS AND INCOME DISTRIBUTION: EVIDENCE FROM TURKEY*
}

\author{
Yıldırım Beyazıt ÇİÇEN ${ }^{1}$ \\ Ayça KARAKUZU²
}

\begin{abstract}
Income distribution inequality is one of the important economic problems in Turkey. In addition to economic, social, and political factors, institutional factors also influence income inequality. In this study, the possible effects of institutions on income inequality in Turkey are examined. For this purpose, regional income inequality in Turkey is analyzed by panel data method using regional data between 2009 and 2019. Variables representing the institutional structure such as infant mortality rate, number of illiterate, number of faculty or college graduates, number of doctoral graduates, and number of convicts were used. In addition, the number of financial services local units, the average number of employees in the financial sector, internet access in households, the proportion of individuals using the internet regularly, and the net migration rate variables were also used as control variables. According to the findings obtained from the models, the variables of illiterate number, number of college or faculty graduates, internet access rate in households, and infant mortality rate are statistically significant on income distribution.
\end{abstract}

Keywords: Institutions, Income Distrubution, Regions, Turkey

JEL Codes: D02, O15, O18

\section{KURUMLAR VE GELİR DAĞILIMI İLIŞKISII: TÜRKIYY'DEN KANITLAR}

\section{$\ddot{\mathbf{O} z}$}

Gelir eşitsizliği Türkiye'nin önemli iktisadi sorunlarından bir tanesidir. Ekonomik, sosyal ve politik faktörlerin yanı sıra kurumsal faktörler de gelir eşitsizliğini etkilemektedir. Bu çalışmada Türkiye'de kurumların gelir eşitsizliği üzerindeki olası etkileri incelenmiştir. Bu amaçla Türkiye'de bölgesel gelir eşitsizliği 2009-2019 yılları arasında bölge verileri kullanılarak panel veri yöntemiyle analiz edilmiştir. Analizde kurumsal yapıyı temsil eden değişkenler olarak bebek ölüm hızı, okuma yazma bilmeyen sayısı, fakülte veya yüksekokul mezunu sayısı, doktora mezunu sayısı ve hükümlü sayısı kullanılmıştır. Ayrıca kontrol değişkeni olarak finansal hizmetler yerel birim sayısı, finans sektöründe ortalama çalışan sayısı, hanelerde internet erişimi, interneti düzenli kullanan bireylerin oranı ve net göç hızı değişkenleri kullanılmıştır. Modellerden elde edilen bulgulara göre, okuma yazma bilmeyen sayısı, yüksekokul veya fakülte mezunu sayısı, hanelerde internet erişim oranı ve bebek ölüm hızı değişkenleri gelir dağılımı üzerinde istatistiksel olarak anlamlıdır.

Anahtar Kelimeler: Kurumlar, Gelir Dağılımı, Bölgeler, Türkiye

JEL Kodları: D02, O15, O18

\footnotetext{
* This study was conducted under the supervision of Yıldırım Beyazıt Çiçen, a Faculty Member at Gümüşhane University Graduate Education Institute, and was produced using Ayça Karakuzu's master's thesis entitled "The Relationship between Corporate Quality and Income Distribution: A Case Study of Turkey”.

${ }^{1}$ Assistant Professor, Gumushane University, ybcicen@gumushane.edu.tr,

${ }^{2}$ Graduate Student, Gumushane University, aycakrkz@gmail.com, (iD

Makalenin Geliş Tarihi (Received Date): 18.11.2021

Revizyon Tarihi (Revised Date): 19.12.2021

Yayına Kabul Tarihi (Acceptance Date): 29.12.2021

Atıf (Citation): Çiçen, Y.B. \& Karakuzu, A. (2021), "Relationship between Instıtutıons and Income Distribution: Evidence from Turkey”, Ekonomi Maliye İşletme Dergisi, 4(2): 155-169
} 


\section{Introduction}

In recent years, there has been an increase in the number of studies on income inequality. Because income inequality affects both emerging and developed countries. The central objective of income distribution studies is to determine the level of inequality in the distribution and to compare the level of inequality between different groups. While income distribution in different periods of a country can be compared in these studies, evaluations of distinct parts of the country can also be done.

Inequalities in income distribution have grown due to globalization. For this reason, income distribution inequalities are at the forefront of economic debates. Inequalities are induced by war and disease, disruptions caused by technological change, problems with access to education, and redistribution. These inequalities in countries can be internal and external (Milanovic, 2016). If income is not allocated fairly within a society, issues such as poverty, social tensions, and political instability can occur.

Literature on income equalities is generally focused on comparing the income inequalities of the countries. Furthermore, studies in this subject are primarily discussed in terms of neoclassical economics. Therefore, countries ignore the institutional reasons that reveal the income distribution, and the problem continues. At this point, it is important to examine Turkey's current and emerging inequalities from several institutional aspects.

This study aims to evaluate whether changes in institutional structure in different regions of Turkey have a good or negative impact on income distribution. This study is anticipated to make the following contributions to the literature: i) Since regional variables are used in the analysis, regional differences can be revealed in the relationship between institutional structure and income distribution in Turkey. ii) Although there are cross-country analyses on this topic in the literature, there are relatively few studies on Turkey. As a result, this research will attempt to fill this gap. iii) Panel data analysis was used in the study. This analysis used many institutional and control variables, and three different models were performed. Besides, specification tests were applied to examine the models' consistency and determine the assumptions deviations. Accordingly, resistant models were estimated. iv) Since the period covered in the study is between 2009 and 2019, the inequalities emerged until the pandemic after the global crisis, and the fluctuations in these inequalities can be revealed more clearly. v) Regional development policies, which take into account the institutional approach that will reduce income inequality in the long run, will be formed more effectively, together with the determination of which institutional variable impacts income inequality and the inferences derived from these findings.

\section{Relationship of Institutions and Income Distribution}

Institutions are defined as the rules of the game played in society (North, 1990: p. 3). Accordingly, institutions shape the relationships between people. The most important role of institutions is to reduce transaction costs. Institutions reduce uncertainty by creating a stable structure among people. Thus, institutions encourage exchange in the political, social, and economic fields. As a result, institutions determine economic performance by influencing production and exchange costs (North, 1994). In addition, the institutional structure defines the opportunity set that provides the highest returns to production activities while effectively redistributing income in an economy (North, 1997: p. 8). Decentralization of political institutions can also affect income distribution. In this case, the design of the institutional structure that realizes redistribution can reveal inequalities. Furthermore, inequalities in the regions may arise due to the regions' internal structures and governance composition (Beramendi, 2003).

When the recent literature is examined, studies on the effects of institutions on economic performance within the Old Institutional Economics and New Institutional Economics schools are frequently encountered. According to the literature, there is a significant relationship between poor institutions and economic inequality. Where an independent judicial system cannot protect the poor, for example, their ability to generate rents will be lower than that of the wealthy. Furthermore, if the wealthy have more political clout, income inequality will rise as institutions become dysfunctional (Chong and Gradstein, 2007: p. 463). Another study showed that the labour market restrictions implemented from 
an institutional perspective impact income inequality. Accordingly, de jure and de facto regulations improve income distribution (Calderon and Chong, 2009).

There are many determinants of income inequality. Income inequality varies depending on many variables, ranging from the factor equipment, geography, institutions, and social capital of a country's economy, historical accumulation, changes in technology, and capital returns. The use of Gross Domestic Product alone is insufficient to explain income inequality. In some countries, high average income levels result from sophisticated industrial structures, and in these countries, institutions tend to be inclusive, and income inequality is diminishing. On the other hand, other countries with high average income levels based on natural resources rarely build inclusive institutions, resulting in significant income inequality (Hartman et al., 2017: pp. 76-77). Moreover, labour market institutions are a significant determinant of wage inequality and unemployment. Since these variables also affect income distribution, better labour market institutions reduce income inequality (Checchi and Peñalosa, 2008).

However, financial liberalization, financial structures, and capitalist market institutions have been shown to diminish income inequality in some cases while increasing it in others. Financial openness and the development of stock markets, for example, help to reduce income inequality. Furthermore, the development of the banking sector worsens income inequalities. Another result is that the higher a country's trust in market institutions, the higher the share of the wealthiest $10 \%$ of its population (Kim et al., 2019; Holcombe and Boudreaux, 2016).

\subsection{Regional Income Distribution and Its Importance}

Income distribution is classified into four main headings: Personal, functional, sectoral, and regional division of national income generated in the country's economy. The discrepancies in regional income distribution and the reasons for differences in Turkey are explored in our research.

The regional income distribution depicts the income share of people living in various regions of the country. Just as the income distribution differs from country to country, in some countries, it differs from region to region (Fischer and Stumpner, 2008).

To improve income inequality, countries should first determine the dynamics of regional convergence or divergence. The country's economic, social, cultural, and political conditions are important factors in determining income distribution. Capital accumulation, investments, total factor productivity, population, migration, and human capital, as well as public policies and economic structures (rural and modern production structures), are the most influential variables in regional economic growth differences (Borluk, 2014: p. 2).

Fair income distribution is essential for social peace and harmony, as well as stable economic growth. In order to increase social welfare, Rawls' distributive justice approach states that the income of the lowest-income individual in society should be increased. Furthermore, Rawls asserts that specific segments of society's fundamental rights and freedoms cannot be sacrificed to increase society's overall benefit. The theory of justice, according to Rawls, should be established in terms of principles and rules (Rawls, 1971). This theory indicates the importance of institutions in income distribution. Increasing the income of the country's poorest region can be considered as an initial solution.

\subsection{Regional Gini Coefficient}

One of the most frequently used methods in measuring income distribution inequality is the Gini coefficient. This method, developed by Corrado Gini in 1912, was calculated using the Lorenz curve. The Gini Coefficient is a single number that expresses the level of income inequality and ranges from 0 to 1 . This coefficient is low, indicating that the income distribution is more equitable. Recently, new formulas have been developed for calculating the Gini coefficient (Dorfman, 1979; Milanovic, 1997). The regional Gini coefficient in Turkey is compiled by the Income and Living Conditions Survey of the Turkish Statistical Institute (TURKSTAT). In the research methodology, geographical coverage, audience investigated, and topics are covered as the main issues regarding the scope of the research. When designing a sample, sampling method, sampling unit, estimation size, sample size and non-response rate, population weights, and panel survey application are considered. Data 
compilation and analysis methods are used in the relevant period, and obtained statistics are presented to the public ${ }^{3}$.

\subsection{The Relationship between Institutions and Income Distribution in Turkey}

Uneven income distribution, which has become a critical challenge, particularly in developing countries, is also a significant problem in the Turkish economy.

A turning point for political and economic institutions in Turkey is 1980. Income distribution in Turkey began to deteriorate with the change that started in the 1980s. Individual, sectoral, regional, and functional income distributions have all been impacted by income distribution distortions. After 1980, pro-market neoliberal policies and the open economy replaced the inward, protectionist, and interventionist industrialization model. However, the role of state and local governments in the distribution and accumulation processes has not diminished. While institutions and democracy could not be strengthened following the 1980 coup, the resulting polarization increased political instability. The military administration resulted in a significant decrease in the worker's income. The segments that rely on labour and agricultural incomes and cannot organize themselves have borne the brunt of structural transformations. Problems in law and the judiciary, political institution weaknesses, and unequal power relations in society persisted after the 1982 Constitution. Furthermore, rapid population growth, unemployment, and rising inflation rates have hurt income distribution. The income distribution problem was attempted to be addressed through development plans, but the desired results were not achieved by the policies implemented (Özdemir and İslamoğlu, 2017, 125; Pamuk, 2012, 276-311).

In comparison to previous years, there was a significant increase in political instability in the 1990s. Inflation was high, and devaluations were frequent in the 1990s. With the help of collective agreements, support purchases, and low-interest loans, organized sections of society have protected themselves from high inflation and devaluations. Moreover, the impact of high inflation has spread to more unorganized and politically powerless groups (Pamuk, 2012: p. 277-278). These economic problems affecting the base of society and the 2000-2001 crisis also affected the political structure, and the proportions of the centre-right parties shifted to the Justice and Development Party.

When the regional income distribution of Turkey is examined, significant social and economic imbalances stand out. For this reason, the analysis of regional income distribution, as well as personal distribution in Turkey, is an issue that should be considered. Aside from agriculture, industry, and services, variations in education, health, and transportation cause income disparities between regions. It is necessary to investigate the factors that cause income inequality and develop solutions to this problem by evaluating the findings to ensure a balanced regional income distribution (Kuştepeli and Halaç, 2004: p. 155).

The annual average disposable income for 2020 in different regions of Turkey is shown in Figure 1. The income of the relevant region increases as the colours in the figure darken. The figure clearly shows that income inequality in the regions is disturbingly high. Istanbul (TR10) had the highest income, with 49 thousand 239 TL, while Van, Muş, Bitlis, and Hakkari (TRB2) had the lowest income, with 15 thousand 198 TL.

\footnotetext{
${ }^{3}$ https://webcache.googleusercontent.com/search?q=cache:VjYdWjSNLgQJ:https://data.tuik.gov.tr/Bulten/DownloadFil e\%3Fp\%3DGqxaV2svT1uJ1rg7chcWJIWX1/8gsOGLDeEJUq3LOhVV5xabS2JpLnYXbBMN7cPZriER7amNUEuya6 3zMQrcFKfu9UkvJfAqYqgbuJnEOC8\%3D+\&cd=4\&hl=tr\&ct=clnk\&gl=tr - Access Date: 05.11 .2021
} 


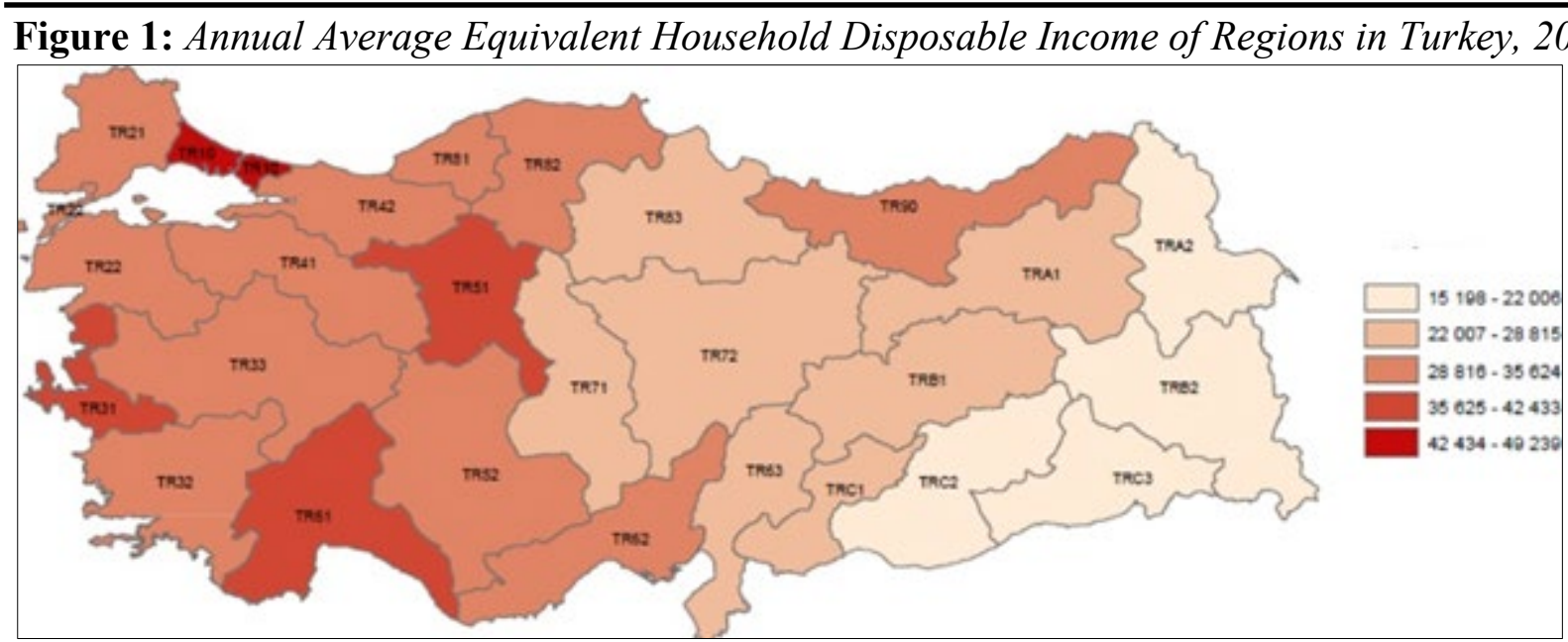

Source: TURKSTAT, Income and Living Conditions Survey Regional Results, 2020

The regional income inequality divergence in Turkey's various regions can be seen from Table 1, showing the Gini coefficient values by region. The Gini coefficient difference between the regions increased up to 1 point in some years. Despite fluctuations, the income distribution of the regions has improved between 2006 and 2019, except Istanbul and the West Marmara Regions. Furthermore, the Gini coefficients increased due to the global financial crisis and generally decreased after 2016.

The institutional cause of the Gini coefficient fluctuations after 2006 should be investigated. Following the crisis of 2000-2001, Turkey embarked on a series of reforms, aided by the European Union's (EU) entry process. These reforms improved not only the institutional structure but also improved economic indicators. Institutional reforms could not be continued after the global financial crisis. The slowing of the EU membership process, the strengthening of the single-party government, the Gezi events, the failed coup attempt, and the subsequent declaration of emergency are some of the reasons for this slowdown (Gürkaynak and Böke, 2013; Acemoğlu and Robinson, 2020, 488490). The economic consequences of these negative institutional changes were also reflected in the income distribution. According to TURKSTAT, the personal income Gini coefficient was 0.440 in 2002 and decreased to 0.380 in 2005. This improvement in income distribution is a result of the reforms. With the effect of the global crisis, the Gini coefficient increased in 2009 and became 0.415. After the global crisis, the improvement in income distribution did not continue at the same pace. The Gini coefficient decreased from 0.402 in 2010 to 0.397 in 2015 and then rose in the following years. The Gini coefficient increased to 0.410 in 2019 due to the pandemic period.

Table 1: Gini Coefficient by Region in Turkey, 2006-2019

(Equivalent Household Disposable Individual Income Calculation Method)

\begin{tabular}{|l|l|l|l|l|l|l|l|l|l|l|l|l|l|l|}
\hline \multicolumn{10}{|c|}{ Years } \\
\begin{tabular}{|l|l|l|l|l|l|l|l|l|l|l|l|} 
Gini \\
Coefficient
\end{tabular} & $\mathbf{2 0 0 6}$ & $\mathbf{2 0 0 7}$ & $\mathbf{2 0 0 8}$ & $\mathbf{2 0 0 9}$ & $\mathbf{2 0 1 0}$ & $\mathbf{2 0 1 1}$ & $\mathbf{2 0 1 2}$ & $\mathbf{2 0 1 3}$ & $\mathbf{2 0 1 4}$ & $\mathbf{2 0 1 5}$ & $\mathbf{2 0 1 6}$ & $\mathbf{2 0 1 7}$ & $\mathbf{2 0 1 8}$ & $\mathbf{2 0 1 9}$ \\
\hline Istanbul & 0.361 & 0.344 & 0.35 & 0.35 & 0.355 & 0.358 & 0.374 & 0.381 & 0.357 & 0.378 & 0.398 & 0.43 & 0.427 & 0.417 \\
\hline $\begin{array}{l}\text { West } \\
\text { Marmara }\end{array}$ & 0.359 & 0.335 & 0.336 & 0.37 & 0.371 & 0.378 & 0.38 & 0.359 & 0.37 & 0.382 & 0.395 & 0.402 & 0.418 & 0.387 \\
\hline Aegean & 0.412 & 0.372 & 0.382 & 0.384 & 0.387 & 0.4 & 0.391 & 0.382 & 0.373 & 0.378 & 0.387 & 0.387 & 0.379 & 0.367 \\
\hline East Marmara & 0.39 & 0.38 & 0.332 & 0.364 & 0.328 & 0.323 & 0.342 & 0.329 & 0.351 & 0.353 & 0.346 & 0.361 & 0.356 & 0.322 \\
\hline West Anatolia & 0.399 & 0.368 & 0.396 & 0.388 & 0.358 & 0.364 & 0.357 & 0.388 & 0.393 & 0.385 & 0.394 & 0.374 & 0.387 & 0.36 \\
\hline Mediterranean & 0.402 & 0.413 & 0.373 & 0.387 & 0.388 & 0.395 & 0.396 & 0.394 & 0.392 & 0.392 & 0.396 & 0.388 & 0.393 & 0.371 \\
\hline $\begin{array}{l}\text { Middle } \\
\text { Anatolia }\end{array}$ & 0.359 & 0.34 & 0.344 & 0.4 & 0.369 & 0.363 & 0.361 & 0.343 & 0.365 & 0.362 & 0.386 & 0.358 & 0.37 & 0.368 \\
\hline $\begin{array}{l}\text { West Black } \\
\text { Sea }\end{array}$ & 0.367 & 0.366 & 0.375 & 0.382 & 0.345 & 0.333 & 0.337 & 0.329 & 0.339 & 0.358 & 0.368 & 0.359 & 0.373 & 0.358 \\
\hline East Black Sea & 0.393 & 0.359 & 0.371 & 0.373 & 0.328 & 0.337 & 0.332 & 0.328 & 0.333 & 0.336 & 0.369 & 0.342 & 0.347 & 0.364 \\
\hline $\begin{array}{l}\text { Northeast } \\
\text { Anatolia }\end{array}$ & 0.364 & 0.395 & 0.434 & 0.388 & 0.372 & 0.373 & 0.37 & 0.385 & 0.394 & 0.378 & 0.352 & 0.334 & 0.347 & 0.338 \\
\hline
\end{tabular}




\begin{tabular}{|c|c|c|c|c|c|c|c|c|c|c|c|c|c|c|}
\hline $\begin{array}{l}\text { Middle East } \\
\text { Anatolia }\end{array}$ & 0.38 & 0.374 & 0.369 & 0.385 & 0.384 & 0.383 & 0.356 & 0.35 & 0.367 & 0.355 & 0.37 & 0.352 & 0.336 & 0.33 \\
\hline $\begin{array}{l}\text { Southeast } \\
\text { Anadolu }\end{array}$ & 0.381 & 0.355 & 0.393 & 0.401 & 0.382 & 0.378 & 0.348 & 0.362 & 0.361 & 0.363 & 0.349 & 0.347 & 0.371 & 0.367 \\
\hline
\end{tabular}

Source: TURKSTAT, Income Distribution and Living Conditions Statistics

\section{Econometric Analysis}

In this section, the factors that determine the relationship between institutions and income distribution are revealed by Turkey's regional data. While determining the independent and control variables in the model, factors that may reveal inequalities in income distribution in the relevant region were taken into account. For example, variables such as the number of illiterates reflecting equal opportunities in education and health, the number of graduates of colleges or faculties, and the infant mortality rate were used (Sosnaud, 2019; Corak, 2013). Besides, internet access and finance sector variables were used to determine whether there is an environment for increasing income in the relevant region. As the probability of conviction of disadvantaged individuals will increase with the problems that may arise in the regions, the number of convicts has also been included as a control variable. This variable is the proxy of the governance capacity of the state in the relevant region. Because the markets of law, politics, and economics are alternatives to each other (Oğuz, 2010: p. 233). Accordingly, the decrease in the number of convicts in an economically and socially systematic and fair region is expected to be an outcome of our study. However, it should be noted that the variables added to the model were selected under the data constraint. The variables used in the model are shown in Table 2.

Table 2: Variables Used in the Model

\begin{tabular}{|l|l|}
\hline Variables & Notation \\
\hline Gini Coefficient by Household Disposable Income & gini \\
\hline+15 Age and Illiterate & illiterate \\
\hline Number of College or Faculty Graduates & faculty \\
\hline Number of Doctoral Graduates & doctorate \\
\hline Internet Access in Households (\%) & hint \\
\hline Net Migration Rate (\%) & migration \\
\hline Number of Convicts Entering the Penitentiary Institution & convict \\
\hline Infant Mortality Rate (\%) & mortality \\
\hline Number of Financial Service Local Units & flocal \\
\hline Financial Sector Annual Avg. Number of Employees & femployee \\
\hline Proportion of Individuals Using Regular Internet (\%) & rint \\
\hline
\end{tabular}

Table 3 shows the correlation table for the variables used. Some variables have correlation values above 0.80 , according to this table. Variables were included in the model considering the VIF criteria to avoid biased estimates (variance inflation factor).

Table 3: Correlation Table

\begin{tabular}{|c|c|c|c|c|c|c|c|c|c|c|c|}
\hline & gini & mortality & illiterate & faculty & doctorate & flocal & femployee & hint & rint & convict & migration \\
\hline gini & 1 & & & & & & & & & & \\
\hline mortality & -0.059 & 1 & & & & & & & & & \\
\hline illiterate & 0.2122 & 0.1822 & 1 & & & & & & & & \\
\hline faculty & 0.4737 & -0.11 & 0.6688 & 1 & & & & & & & \\
\hline doctorate & 0.4756 & -0.16 & 0.615 & 0.9782 & 1 & & & & & & \\
\hline flocal & 0.478 & -0.292 & 0.6527 & 0.9702 & 0.958 & 1 & & & & & \\
\hline femployee & 0.4795 & -0.289 & 0.6274 & 0.9598 & 0.9653 & 0.985 & 1 & & & & \\
\hline hint & 0.1769 & 0.2333 & -0.122 & 0.3886 & 0.3862 & 0.236 & 0.2688 & 1 & & & \\
\hline rint & 0.2881 & 0.0268 & -0.125 & 0.5054 & 0.5242 & 0.396 & 0.4228 & 0.903 & 1 & & \\
\hline
\end{tabular}




\begin{tabular}{|c|c|c|c|c|c|c|c|c|c|c|c|}
\hline convict & 0.4828 & 0.0251 & 0.6168 & 0.9504 & 0.8975 & 0.898 & 0.8582 & 0.44 & 0.526 & 1 & \\
\hline migration & 0.1305 & -0.453 & -0.115 & 0.3464 & 0.3283 & 0.376 & 0.3548 & 0.217 & 0.374 & 0.3085 & 1 \\
\hline
\end{tabular}

Descriptive statistics are given in Table 4.

Table 4: Descriptive Statistics

\begin{tabular}{|c|c|c|c|c|}
\hline Variable & Mean & Std. Dev. & Min & Max \\
\hline gini & 0.3682576 & 0.0224722 & 0.322 & 0.43 \\
\hline mortality & 10.50183 & 2.624359 & 6.316 & 17.455 \\
\hline illiterate & 236896 & 140725 & 53731 & 880335 \\
\hline faculty & 613412.6 & 479948 & 76142 & 2294398 \\
\hline doctorate & 13111.1 & 12458.58 & 1859 & 53736 \\
\hline flocal & 1180.833 & 980.6879 & 229 & 4281 \\
\hline femployee & 18579.83 & 25685.28 & 2204 & 105878 \\
\hline hint & 63.65833 & 18.75477 & 21.2 & 95.6 \\
\hline rint & 48.07315 & 15.67215 & 20.5 & 85.2 \\
\hline convict & 13723.08 & 11053.3 & 1306 & 50119 \\
\hline migration & -1.415083 & 8.543058 & -21.116 & 30.541 \\
\hline
\end{tabular}

Three basic models were developed in our research. The goal is to see how different variables affect income inequality. The first model was formulated in the following equation:

gini $_{i t}=\beta_{0}+\mu_{i}+\beta_{1}\left(\right.$ illiterate $\left._{i t}\right)+\beta_{2}\left(\right.$ faculty $\left._{i t}\right)+\beta_{3}\left(\right.$ hint $\left._{i t}\right)+\beta_{4}\left(\right.$ migration $\left._{i t}\right)+\varepsilon_{i t}$

In the first model, the Gini coefficient was used as the dependent variable, while the number of illiterates, the number of faculty or college graduates, internet access in households, and net migration rate were used as independent variables.

The second model equation is as follows:

gini $_{i t}=\beta_{0}+\mu_{i}+\beta_{1}\left(\right.$ illiterate $\left._{i t}\right)+\beta_{2}\left(\right.$ faculty $\left._{i t}\right)+\beta_{3}\left(\right.$ hint $\left._{i t}\right)+\beta_{4}\left(\right.$ convict $\left._{i t}\right)+\varepsilon_{i t}$

While the Gini coefficient was the dependent variable in the second model, unlike the first model, the number of convicts was used instead of the net migration rate as the independent variable.

The third model equation is as follows:

$\operatorname{gini}_{i t}=\beta_{0}+\mu_{i}+\beta_{1}\left(\right.$ faculty $\left._{i t}\right)+\beta_{2}\left(\right.$ hint $\left._{i t}\right)+\beta_{3}\left(\right.$ convict $\left._{i t}\right)+\varepsilon_{i t}$

In the third model, the number of independent variables was reduced to three, and unlike the second model, the number of illiterates was not used.

The logarithms of the variables of illiteracy, graduates of faculties or colleges, and convicts were used in the models. As a result, our models are semi-logarithmic. The coefficients of the number of illiterate people, faculty, and college graduates are expected to be positive in the models. Because increases in these variables will cause societal education levels to diverge, resulting in a disparity of the labour income. Since increasing internet access in households will improve income distribution due to job postings and facilitating access to information, as well as creating new job opportunities and lowering contract and transaction costs, a negative coefficient is expected.

Table 5 gives VIF values. Since VIF values are below 10, using variables together will not create a multicollinearity problem, and these variables can be used in the same model. 
Table 5: VIF values

\begin{tabular}{|c|c|c|c|}
\hline \multirow{2}{*}{ gini } & Random & Random & $\begin{array}{c}\text { Fixed } \\
\text { Effects 1 }\end{array}$ \\
\cline { 2 - 4 } & Effects 1 & Effects 2 & \\
\hline illiterate & 1.67 & 1.31 & \\
\hline faculty & 2.41 & 5.82 & 5.43 \\
\hline hint & 1.79 & 1.79 & 1.47 \\
\hline migration & 1.61 & & \\
\hline convict & & 5.89 & 5.88 \\
\hline
\end{tabular}

Three models were estimated separately with Fixed and Random Effects model using static panel data method. The results of the estimations are presented in Table 6. Since the hint variable does not have data for 2009 and 2010, the number of observations is 108 . It can be seen that from Table 6, it is clear that all models are significant as a whole.

Table 6: Fixed and Random Effects Model Estimates

\begin{tabular}{|c|c|c|c|c|c|c|}
\hline gini & $\begin{array}{c}\text { Fixed } \\
\text { Effects } 1 \\
\end{array}$ & $\begin{array}{l}\text { Random } \\
\text { Effects } 1 \\
\end{array}$ & $\begin{array}{c}\text { Fixed } \\
\text { Effects } 2 \\
\end{array}$ & $\begin{array}{l}\text { Random } \\
\text { Effects } 2 \\
\end{array}$ & $\begin{array}{c}\text { Fixed } \\
\text { Effects } 3\end{array}$ & $\begin{array}{l}\text { Random } \\
\text { Effects } 3 \\
\end{array}$ \\
\hline \multirow{2}{*}{ illiterate } & 0.059 & -0.023 & 0.036 & -0.017 & & \\
\hline & -0.06 & -0.023 & -0.067 & -0.024 & & \\
\hline \multirow{2}{*}{ faculty } & $0.191 * * *$ & $0.054 * * *$ & $0.227 * * *$ & 0.043 & $0.223 * * *$ & 0.034 \\
\hline & -0.062 & -0.018 & -0.077 & -0.027 & -0.076 & -0.024 \\
\hline \multirow[t]{2}{*}{ hint } & $\begin{array}{c}- \\
0.0008 * * * \\
\end{array}$ & $-0.0003 *$ & $\begin{array}{c}- \\
0.0008 * * * \\
\end{array}$ & $-0.0003 *$ & $-0.009 * * *$ & -0.0002 \\
\hline & -0.0003 & -0.0002 & -0.0003 & -0.0002 & -0.003 & -0.0001 \\
\hline \multirow{2}{*}{ migration } & -0.001 & -0.0002 & & & & \\
\hline & -0.0003 & -0.0003 & & & & \\
\hline \multirow{2}{*}{ convict } & & & -0.002 & 0.064 & -0.028 & 0.011 \\
\hline & & & -0.027 & -0.019 & -0.024 & -0.018 \\
\hline \multirow{2}{*}{ constant } & $-0.982 *$ & 0.199 & $-0.977^{*}$ & 0.203 & $-0.738^{*}$ & 0.144 \\
\hline & -0.573 & -0.132 & -0.572 & -0.132 & -0.351 & -0.09 \\
\hline $\begin{array}{l}\text { Number of } \\
\text { Observations }\end{array}$ & 108 & 108 & 108 & 108 & 108 & 108 \\
\hline $\begin{array}{c}\text { Number of } \\
\text { Regions }\end{array}$ & 12 & 12 & 12 & 12 & 12 & 12 \\
\hline $\mathrm{R}^{2}$ & 0.165 & 0.223 & 0.171 & 0.216 & 0.183 & 0.206 \\
\hline F Test/ & 2.78 & 9.81 & 2.86 & 9.01 & 3.75 & 8.92 \\
\hline $\begin{array}{l}\text { Wald chi- } \\
\text { square }\end{array}$ & -0.031 & -0.044 & -0.028 & -0.06 & -0.014 & -0.03 \\
\hline
\end{tabular}

Note: $* * *, * * *$ respectively indicate significance levels at $10 \%, 5 \%$, and $1 \%$ levels.

The Hausman test was applied to choose between the Random Effects and Fixed Effects models. Table 7 shows the Hausman test results for the three models.

Table 7: Hausman Tests

\begin{tabular}{|l|c|c|c|}
\hline & Model 1 & Model 2 & Model 3 \\
\hline Chi2 test statistics & 7.18 & 6.84 & 6.85 \\
\hline p-value & 0.1266 & 0.1448 & 0.0769 \\
\hline
\end{tabular}

The Fixed Effects estimator allows explanatory variables to be associated with unobservable timeconstant effects, while the Random Effects estimator does not allow this relationship. In the Hausman test, the null hypothesis is that "the difference between the parameters is not systemic." Accordingly, the Random Effects model is consistent under the hypothesis, and the Random Effects model is 
preferred. When the null hypothesis is rejected, the Fixed Effects model is consistent, then, Fixed Effects model is preferred. In the related test, the decision is made over the probability statistics of the calculated Chi-square test.

The null hypothesis cannot be rejected when the Fixed and Random Effects 1 models are compared using the Hausman test because the $p$-value obtained from the test is greater than the $10 \%$ significance level $(0.1266>0.10)$, so the Random Effects model is preferred in the first model. Similarly, the null hypothesis cannot be rejected in the Hausman test for Fixed and Random Effects 2 models because the $p$-value is greater than the $10 \%$ significance level $(0.1448>0.10)$, and the Random Effects model is preferred for the second model. In comparing Fixed and Random Effects 3 models, however, the null hypothesis is rejected, and the Fixed Effects model is preferred because the p-value is less than $10 \%$ significance level $(0.0769<0.10)$.

\subsection{Assumption Tests}

At this point, the preferred Random and Fixed Effects models will be evaluated by assumption tests. It will not be correct to use the relevant models if the assumptions are not realized in the relevant models because the results obtained from the models will be biased.

Heteroscedasticity, autocorrelation, and cross-section dependence tests are applied as assumption tests regarding the models. The assumption tests were performed on the Random Effects 1 and 2 models and the Fixed Effects 3 model suggested by the Hausman test. Assumption tests were applied for each of the three models separately. The cross-section dependence test is not used in Random Effects models. Because units in a random-effects analysis are chosen randomly, no correlation between units is expected (Yerdelen Tatoğlu, 2016: p. 233).

\subsubsection{Assumption Tests for Random Effects Models}

Heteroscedasticity and autocorrelation tests will be performed for the Random Effects models.

\subsubsection{Heteroscedasticity Test for Random Effects 1 and Random Effects 2 Models}

The assumption of heteroscedasticity was tested using the Levene, Brown, and Forsythe test, which is utilized in the Random Effects model (Levene, 1960; Brown and Forsythe, 1974). Table 8 displays the test results. "The variance of the units is equal (there is no heteroscedasticity)" is the null hypothesis of this test. The null hypothesis is not accepted when the probability values are less than 0.05 .

Table 8: Heteroscedasticity Test for Random Effects 1 and 2 Models

\begin{tabular}{|c|l|}
\hline \multirow{2}{*}{$\begin{array}{c}\text { Levene, Brown and Forsythe Test } \\
\text { (Model 1) }\end{array}$} & $\mathrm{W} 0=2.5832214 \mathrm{df}(11,96) \mathrm{Pr}>\mathrm{F}=0.00644632$ \\
\cline { 2 - 3 } & $\mathrm{W} 50=1.4245367 \mathrm{df}(11,96) \mathrm{Pr}>\mathrm{F}=0.17442178$ \\
\cline { 2 - 2 } $\begin{array}{c}\text { Levene, Brown and Forshtye Test } \\
\text { (Model 2) }\end{array}$ & $\mathrm{W} 10=2.5832214 \mathrm{df}(11,96) \mathrm{Pr}>\mathrm{F}=0.00644632$ \\
\cline { 2 - 3 } \begin{tabular}{c} 
(M0 \\
\cline { 2 - 3 }
\end{tabular} & $\mathrm{W} 0=2.8121290 \mathrm{df}(11,96) \mathrm{Pr}>\mathrm{F}=0.00320516$ \\
\cline { 2 - 3 } & $\mathrm{W} 10=2.8121290 \mathrm{df}(11,96) \mathrm{Pr}>\mathrm{F}=0.00320516$ \\
\hline
\end{tabular}

The mean and standard deviations of the residuals of 12 units (12 regions) are shown in Table 8 . The $H_{0}$ hypothesis (the variances of the units are equal) is not accepted when the Levene, Brown, and Forsythe test statistics (W0, W50, and W10) are compared to the Snedecor F table with $(11,96)$ degrees of freedom. As a result, the Random Effects 1 and Random Effects 2 models have heteroscedasticity.

\subsubsection{Autocorrelation Test for Random Effects 1 and Random Effects 2 Models}

The Augmented Lagrange Multiplier (ALM) test of Breusch and Pagan (1980) is used as the autocorrelation test, and the results are shown in Table 9. The null hypothesis in this test is that "there is no correlation between error terms." 


Table 9: Autocorrelation Test for Random Effects 1 and 2 Models
\begin{tabular}{|c|l|}
\hline Augmented Lagrange & Serial Correlation: \\
Multiplier & ALM $(\operatorname{Var}(\mathrm{u})=0)=6.85 \operatorname{Pr}>\operatorname{chi} 2(1)=$ \\
Model 1 & 0.0089 \\
\hline Augmented & Serial Correlation: \\
Lagrange Multiplier & ALM $(\operatorname{Var}(\mathrm{u})=0)=9.88 \quad \operatorname{Pr}>\operatorname{chi} 2(1)=$ \\
Model 2 & 0.0017 \\
\hline
\end{tabular}

$H_{0}$ is rejected based on the ALM test results in Table 9. As a result, autocorrelation can be determined in the Random Effects 1 and Random Effects 2 models.

\subsubsection{Assumption Tests for the Fixed Effects 3 Model}

Heteroscedasticity, autocorrelation, and cross-section dependence tests will be performed for the Fixed Effects model.

\subsubsection{Heteroscedasticity Test for Fixed Effects 3 Model}

According to the Hausman test, the assumption tests were applied to the Fixed Effects 3 model. The Modified Wald test (Greene, 2000) was used to test the homoscedasticity assumption in the Fixed Effects model, and the test results are shown in Table 10. This test's null hypothesis proves that there is no heteroscedasticity. The variances are homoscedastic to units, in other words. The null hypothesis is not accepted as the Chi-square probability values are less than 0.05 , indicating heteroscedasticity.

Table 10: Heteroscedasticity Test for Fixed Effects 1 Model

\begin{tabular}{|l|l|l|}
\hline \multirow{3}{*}{ Modified Wald test } & Chi-square test statistic & 30.78 \\
\cline { 2 - 3 } & p-value & 0.002 \\
\hline
\end{tabular}

Table 10 shows the probability value and the chi-square test statistic with 12 degrees of freedom. The null hypothesis is rejected, and it is understood that the variance varies according to the units (selected regions), leading to the conclusion that heteroscedasticity exists.

\subsubsection{Autocorrelation Test for Fixed Effects 3 Model}

The autocorrelation assumption was tested using the Bhargava, Franzini, and Narendranathan (1982) and Baltagi-Wu (1999) tests for the Fixed Effects model, and the results are shown in Table 11. The null hypothesis in these tests is that "there is no autocorrelation."

Table 11: Autocorrelation Test for Fixed Effects 3 Model

\begin{tabular}{|l|l|}
\hline Bhargava v.d. Durbin Watson Test & 1.0160021 \\
\hline Baltagi-Wu LBI Test & 1.3243802 \\
\hline
\end{tabular}

Table 11 shows the test statistics for both tests but not the probability values. Although critical values are not given in the literature, it is assumed that autocorrelation is important if the test statistics are less than 2 (Yerdelen Tatoğlu, 2016: p. 226). According to both test results, the Fixed Effects 3 model has autocorrelation because the statistics are less than 2 .

\subsubsection{Cross-Section Dependence Test for the Fixed Effects 3}

The cross-section dependence test was performed using the Pesaran (2004) and Friedman (1937) tests in the Fixed Effects 3 model. The results of the tests are presented in Table 12.

The upper part of the table shows cross-section dependence findings (test statistic and probability value) based on the Pesaran test. There is no correlation between units, according to the null hypothesis. As the null hypothesis cannot be rejected, the Pesaran test findings show no correlation between units. 
Table 12: Cross-Section Dependence Test for the Fixed Effects 3

\begin{tabular}{|l|c|}
\hline Pesaran Test & $1.591, \operatorname{Pr}=0.1117$ \\
\hline Friedman's Test & $15.022, \operatorname{Pr}=0.1815$ \\
\hline
\end{tabular}

Friedman's test is non-parametric. This test's null hypothesis is no correlation between the units. The table shows Friedman's test statistic and probability value. According to the findings, the $H_{0}$ hypothesis cannot be rejected, and there is no correlation between the units.

There is no cross-section dependence in the assumption tests, but models have heteroscedasticity and autocorrelation. For this reason, the estimates from the Fixed and Random Effects models will be biased. As a result, resistant models have been performed to make unbiased predictions.

\subsection{Robust Estimators}

If there is a deviation from the assumption, an appropriate corrective method for the specific deviation should be chosen. In the presence of heteroscedasticity and autocorrelation, Arellano, Froot, and Rogers (Arellano (1987), Froot (1989), and Rogers (1993)) and Newey and West (1987, 1994) estimators can be used in Fixed and Random Effects models.

In the presence of heteroscedasticity and autocorrelation, the Arellano, Froot, and Rogers estimator shows the estimator with clustered standard errors. This method's standard errors are lower, despite the exact coefficient estimates. The Newey-West estimator uses a generalized moment-based estimation method. This model reduces standard errors when compared to the classical model. Furthermore, the coefficients of the variables vary (Yerdelen Tatoğlu, 2016: p. 256-261).

Table 13 shows the results of the robust estimators for the Random Effects 1, Random Effects 2, and Fixed Effects 3 models.

Table 13: Robust Estimators

\begin{tabular}{|c|c|c|c|c|c|c|}
\hline \multirow[b]{2}{*}{ gini } & \multicolumn{2}{|c|}{$\begin{array}{l}\text { Robust Models for Random } \\
\text { Effects } 1\end{array}$} & \multicolumn{2}{|c|}{$\begin{array}{l}\text { Robust Models for Random } \\
\text { Effects } 2\end{array}$} & \multicolumn{2}{|c|}{$\begin{array}{l}\text { Robust Models for Random } \\
\text { Effects } 3\end{array}$} \\
\hline & $\begin{array}{c}\text { Arellano, } \\
\text { Froot and } \\
\text { Rogers }\end{array}$ & Newey-West & $\begin{array}{c}\text { Arellano, } \\
\text { Froot and } \\
\text { Rogers }\end{array}$ & Newey-West & $\begin{array}{c}\text { Arellano, } \\
\text { Froot and } \\
\text { Rogers } \\
\end{array}$ & Newey-West \\
\hline illiterate & $\begin{array}{c}-0.023 \\
('-0.027)\end{array}$ & $\begin{array}{l}-0.025^{*} \\
(' 0.131)\end{array}$ & $\begin{array}{l}-0.017 \\
(0.027)\end{array}$ & $\begin{array}{l}-0.014 \\
(' 0.131)\end{array}$ & & \\
\hline faculty & $\begin{array}{c}0.054 * * * \\
(0.014)\end{array}$ & $\begin{array}{c}0.049 * * * \\
(0.01)\end{array}$ & $\begin{array}{c}0.043 \\
(0.026)\end{array}$ & $\begin{array}{c}0.019 \\
(0.015)\end{array}$ & $\begin{array}{l}0.223 * * * \\
(0.052)\end{array}$ & $\begin{array}{c}0.014 \\
(0.016)\end{array}$ \\
\hline hint & $\begin{array}{l}-0.0003 \\
(0.0002)\end{array}$ & $\begin{array}{l}-0.0003^{*} \\
(0.0001)\end{array}$ & $\begin{array}{l}-0.0003 \\
(0.0002)\end{array}$ & $\begin{array}{c}-0.002 \\
(0.0001)\end{array}$ & $\begin{array}{l}-0.009 * * \\
(0.0003)\end{array}$ & $\begin{array}{c}-0.002 \\
(0.0001)\end{array}$ \\
\hline Migration & $\begin{array}{l}-0.0002 \\
(0.0004)\end{array}$ & $\begin{array}{l}-0.0005 \\
(0.0003)\end{array}$ & & & & \\
\hline convict & & & $\begin{array}{c}0.064 \\
(0.026)\end{array}$ & $\begin{array}{c}0.023 * * * \\
(0.013)\end{array}$ & $\begin{array}{l}-0.028 \\
(0.029)\end{array}$ & $\begin{array}{l}0.024^{*} \\
(0.013)\end{array}$ \\
\hline constant & $\begin{array}{l}0.199^{*} \\
(0.115)\end{array}$ & $\begin{array}{c}0.235^{* * *} \\
(0.075)\end{array}$ & $\begin{array}{l}0.203^{*} \\
(0.113)\end{array}$ & $\begin{array}{c}0.256^{*} \\
(0.08)\end{array}$ & $\begin{array}{c}-0.738^{* *} \\
(0.255)\end{array}$ & $\begin{array}{l}0.204 * * * \\
(0.054)\end{array}$ \\
\hline $\begin{array}{c}\text { Number of } \\
\text { Observations }\end{array}$ & 108 & 108 & 108 & 108 & 108 & 108 \\
\hline Number of Regions & 12 & 12 & 12 & 12 & 12 & 12 \\
\hline $\mathrm{R}^{2}$ & 0.223 & - & 0.216 & - & 0.183 & - \\
\hline $\begin{array}{l}\text { Wald chi-square / } \\
\text { F test }\end{array}$ & $\begin{array}{c}36.97 \\
(0.0000)\end{array}$ & $\begin{array}{c}6.71 \\
(0.0001)\end{array}$ & $\begin{array}{c}31.61 \\
(0.0000)\end{array}$ & $\begin{array}{c}6.17 \\
(0.0002)\end{array}$ & $\begin{array}{c}7.01 \\
(0.0066)\end{array}$ & $\begin{array}{c}7.90 \\
(0.0001)\end{array}$ \\
\hline
\end{tabular}

It can be concluded from Table 13 that all of the models are significant. In the Random Effects 1 model, the number of faculty and college graduates as an independent variable in the Arellano, Froot and Rogers estimator is significant at the $1 \%$ level. According to the Newey-West estimator of the same model, the number of faculty or college graduates is significant at the $1 \%$ level, while the variables of illiteracy and internet access in households are significant at the $10 \%$ level. 
The independent variables in the Random Effects 2 model are not significant in the Arellano, Froot, and Rogers estimator. Only the number of convicts variable is significant at the $1 \%$ level in the Newey-West estimator.

The number of faculty and college graduates is significant at the level of $1 \%$ in the Fixed Effects 3 model, according to the Arellano, Froot, and Rogers estimator, and internet access in households is significant at the level of $10 \%$. Only the number of convicts variable is significant at the $10 \%$ level in the Newey-West estimator.

\section{Conclusion}

Studies that emphasize the importance of institutions and institutional structure on economic indicators have recently emerged in the literature. From an institutional standpoint, the reasons for income distribution disparity in different regions of Turkey are revealed in this study. The panel data regression was used to analyze data from 12 different regions of Turkey from 2009 to 2019.

Three different models were estimated in our research. The number of faculties or college graduates stands out as a significant variable in the models. The Gini coefficient rises as the number of faculty or college graduates rise because the higher the income of those with higher education, the greater the income inequality. According to another finding, there is a negative relationship between illiteracy and income inequality. Understandably, the coefficient is negative because illiterate people are less involved in the labour market or work at minimum wage. These two variables reveal the impact of the education sector and human capital on income distribution.

Consequently, the state can reduce income inequality by investing in education over time. Policies in the education sector should be developed in collaboration with the private sector to reduce unemployment and raise average income levels in the short and long term. When developing policies, structural and technological changes in the world and Turkey should be considered.

In both models, the variable of household internet access is significant and reduces income distribution inequality. In recent years, it has been observed that internet access in underdeveloped regions has increased and that there is a convergence with developed regions. Consequently, internet access infrastructure should be made more widely available in developing regions' households, internet access should be encouraged, and access fees should be reduced. As an outcome, raising the percentage of people who use the internet regularly in developing countries will positively impact income distribution. Because the skills, knowledge, and factor equipment needed to compete in specific sectors can only be obtained over the internet.

The number of convicts variable is statistically significant in both models. Besides, in these models the number of convicts variable is significant, while other variables are insignificant. The number of convicts indicates the legal structure of the environment in that region. Therefore, the fact that the coefficient of this variable is positive increases the inequality of income distribution. For this reason, protective measures should be taken by the state to reduce the number of convicts. Turkey's prison population increased nearly fourfold between 2009 and 2019. This increase is significantly higher than the relevant period's population growth rate of $15 \%$. There are also regional differences in the number of convicts. The number of convicts has increased by more than fivefold, particularly in the Eastern Black Sea and Southeastern Anatolia regions. In areas where the number of convicts rises, the state should develop and improve legal processes by considering the type of crime, gender, and age groups. Furthermore, it is critical to develop preventive political, economic, and educational policies before committing a crime.

In the models, the migration variable is not significant. As a result, either positive or negative, migration between regions does not affect income distribution. However, the numbers of immigrants received and given by the regions are examined, the migration to developed areas continues. Improving the institutional environment in developing regions will increase employment opportunities and living standards. This trend will also have a positive impact on the income distribution.

There is a need for more regional studies like this in the literature. This study has been tried to establish a basis for future regional studies. When the causes of regional income distribution differences in Turkey or other countries are discovered using various institutional or economic 
variables, more effective policies to reduce income inequality can be developed. For example, considering the institutional and administrative structures of different states in the United States, the differences in the quality of institutions in these states on income distribution can be investigated. On the other hand, when income inequality is reduced, the problems arising from this inequality in society will also be decreased.

Yazar Katkı Oranı (Author Contributions): Yıldırım Beyazıt ÇIÇEN (\%70), Ayça KARAKUZU $(\% 30)$

Yazarların Etik Sorumlulukları (Ethical Responsibilities of Authors): Bu çalışma bilimsel araştırma ve yayın etiği kurallarına uygun olarak hazırlanmıştır.

Çıkar Çatışması (Conflicts of Interest) : Çalışmadan kaynaklı çıkar çatışması bulunmamaktadır.

İntihal Denetimi (Plagiarism Checking): Bu çalışma intihal tarama programı kullanılarak intihal taramasından geçirilmiştir. 


\section{REFERENCES}

Acemoğlu, D. \& Robinson, J. A. (2016). "Dar Koridor". Çeviri, Yüksel Taşkın. İstanbul: Doğan Kitap.

Arellano, M. (1987). "Computing Robust Standard Errors For Within-Groups Estimators". Oxford Bulletin of Economics and Statistics, 49(4): 431-434.

Baltagi, B. H., \& Wu, P. X. (1999). "Unequally Spaced Panel Data Regressions with AR (1) Disturbances". Econometric Theory, 15(6): 814-823.

Beramendi, P. (2003). Political Institutions and Income Inequality: The Case of Decentralization. (No. SP II, 9). WZB, Markets and Political Economy Working Paper.

Bhargava, A., Franzini, L., \& Narendranathan, W. (1982)." Serial Correlation and The Fixed Effects Model". The Review of Economic Studies, 49(4): 533-549.

Borluk, S. (2014). "Türkiye'de Bölgesel Gelir Dağılımı Iraksaması, Verimlilik ve Diğer Dinamiklerle İlişkisi”. Verimlilik Dergisi, 4: 19-44.

Breusch, T. S., \& Pagan, A. R. (1980). "The Lagrange Multiplier Test and Its Applications to Model Specification in Econometrics". The Review of Economic Studies, 47(1): 239-253.

Brown, M. B. \& Forsythe, A. B. (1974), "Robust Tests for the Equality of Variances". Journal of the American Statistical Association, 69: 364-367.

Calderón, C., \& Chong, A. (2009). "Labor Market Institutions and Income Inequality: An Empirical Exploration". Public Choice, 138(1): 65-81.

Checchi, D., \& García-Peñalosa, C. (2008). "Labour Market Institutions and Income Inequality". Economic Policy, 23(56): 602-649.

Chong, A., \& Gradstein, M. (2007). "Inequality and Institutions". The Review of Economics and Statistics, 89(3): 454-465.

Corak, M. (2013). "Income Inequality, Equality of Opportunity, and Intergenerational Mobility". Journal of Economic Perspectives, 27(3): 79-102.

Dorfman, R. (1979). "A Formula for the Gini Coefficient". The Review of Economics and Statistics, 61(1): 146-149.

Fischer, M. M., \& Stumpner, P. (2008). "Income Distribution Dynamics and Cross-Region Convergence in Europe". Journal of Geographical Systems, 10(2): 109-139.

Friedman, M. (1937). "The Use of Ranks to Avoid the Assumption of Normality Implicit in the Analysis of Variance". Journal of the American Statistical Association, 32(200): 675-701.

Froot, K. A. (1989). "Consistent Covariance Matrix Estimation with Cross-Sectional Dependence and Heteroskedasticity in Financial Data". Journal of Financial and Quantitative Analysis, 24(3): 333-355.

Greene, W. H. (2000). Econometric Analysis. New Jersey: Prentice Hall.

Gürkaynak, R., \& Sayek-Böke, S. (2013). "AKP Döneminde Türkiye Ekonomisi". Birikim Dergisi, 296, 64-69.

Hartmann, D., Guevara, M. R., Jara-Figueroa, C., Aristarán, M., \& Hidalgo, C. A. (2017). "Linking Economic Complexity, Institutions, and Income Inequality". World Development, 93: 75-93.

Holcombe, R. G., \& Boudreaux, C. J. (2016). "Market Institutions and Income Inequality". Journal of Institutional Economics, 12(2): 263-276.

Kim, D. H., Hsieh, J., \& Lin, S. C. (2021). "Financial Liberalization, Political Institutions, and Income Inequality". Empirical Economics, 60(3): 1245-1281. 
Kuştepeli, Y. \& Halaç, U. (2004). “Türkiye'de Genel Gelir Dağılımının Analizi ve İyileştirilmesi”. Dokuz Eylül Üniversitesi Sosyal Bilimler Enstitüsü Dergisi, 6(4): 143-160.

Levene, H. (1960). "Robust Test for Equality of Variances". Editor (I. Olkin). Contributions to Probability and Statistics: Essays in Honor of Harold Hotelling (278-292), California: Stanford University Press.

Milanovic, B. (1997). "A Simple Way To Calculate The Gini Coefficient, And Some İmplications". Economics Letters, 56(1): 45-49.

Milanovic, B. (2016). Global Inequality. Cambridge: Harvard University Press.

Newey, W. K., \& West, K. D. (1987). "A Simple, Positive Semi-Definite, Heteroskedasticity and Autocorrelation Consistent Covariance Matrix". Econometrica, 55: 703-708.

Newey, W. K., \& West, K. D. (1994). "Automatic Lag Selection In Covariance Matrix Estimation". The Review of Economic Studies, 61(4): 631-653.

North, D. C. (1990). Institutions, Institutional Change, and Economic Performance. Cambridge: Cambridge University Press.

North, D. C. (1994). "Economic Performance Through Time". The American Economic Review, 84(3): 359-368.

North, D C. (1997). The Process of Economic Change (Research Paper 128). World Institute for Development Economics Research.

Oğuz, Fuat, (2010), "Rekabetçi Bir Süreç Olarak Hukuk”. Liberal Düşünce Dergisi, 60: 231-248.

Özdemir, M. Ç. \& İslamoğlu, E. (2017). Gelir Dă̆ılımı ve Yoksulluk. Seçkin Yayıncılık: Ankara.

Pamuk Ş. (2012). Türkiye’nin 200 Yıllık İktisadi Tarihi. İstanbul: İş Bankası Kültür Yayınları.

Pesaran, M. H. (2004). General Diagnostic Tests for Cross Section Dependence in Panels (IZA Discussion Paper No. 1240). Institute for the Study of Labor (IZA).

Rawls, J. (1971). 1971: A Theory of Justice. Cambridge, MA: Harvard University Press.

Rogers, W. H. (1993). "Regression Standard Errors in Clustered Samples". Stata Technical Bulletin, 13: $19-23$

Sosnaud, B. (2019). "Inequality in Infant Mortality: Cross-state Variation and Medical System Institutions". Social Problems, 66(1): 108-127.

Yerdelen Tatoğlu, F. (2016). Panel Veri Ekonometrisi: Stata Uygulamalı. 3. Bask1. İstanbul: Beta Yayınlar1. 